\title{
Rise of E-Learning and Covid-19 Pandemic: Lecturer and Students Adaptations on the English Language Teaching and Learning
}

\author{
Eka Mareta Suharyanti ${ }^{1}$, Endah Kurtianti ${ }^{2}$, Muamaroh ${ }^{3}$ \\ Master of English Education, Universitas Muhammadiyah Surakarta ${ }^{1,3}$ \\ Master of English Education, Universitas Sebelas Maret ${ }^{2}$, \\ \{s400190010@student.ums.ac.id ${ }^{1}$, endahkurtianti@student.uns.ac.id², muamaroh@ums.ac.id $\left.{ }^{3}\right\}$
}

\begin{abstract}
COVID-19 pandemic gives an impact on the education program in ELT and Learning. It requires students to adjust e-learning which uses Google Classroom application. Both the lecturer and students have not been ready to operate it. This study aimed to find out the adaptation of the lecturer in ELT and learning by using Google Classroom, students' perceptions about learning grammar, and the impact of the students' achievement on grammar. The present study used a qualitative method. The data were taken from interviews. The results showed that the lecturer created materials on pdf extension, gave the assignment and results in the students' work on Google Classroom. The students' perceptions were they preferred to study in the classroom than used Google Classroom because they had inadequacies internet connections. The tests given were about tenses, passive voice, verb, and parallel structure. The online learning impacted on students' grammar achievement resulted in moderate scores.
\end{abstract}

Keywords: English Language, Grammar, e-Learning, Google Classroom

\section{Introduction}

A study about the use of such online learning in this era has received much attention due to their considerable effect in teaching-learning activities. In this modern era, there are many applications of e-learning which can be used for teaching English. In the past, the teacher rarely even never used this media [Prasetia, 2020) [1]. Coronavirus disease 2019 (COVID-19) deriving from Hubei Province of the People's Republic of China has become a current pandemic over the world (McAleer, 2020) [2]. The World Health Organization (WHO) named this disease COVID-19 on 11 February 2020. Nowadays, everything changes in our life. Many countries have been affected by COVID-19 pandemic including Indonesia. The government tells all people to stay at home to break the chain of distribution of the coronavirus. COVID19 has many impacts in all aspects of human life such as economic, social and also in education.

The process of teaching and learning in formal and informal schools changed, particularly in the English teaching and learning classroom activities. Mustofa (2020) [3] stated that the 
Indonesian Minister of Education instructed teachers and students to conduct distance learning because colleges and schools are locked down. This unprepared situation makes teachers and students use e-learning to keep them learning. This condition also happened in Hong Kong university and initial teacher education (ITE) where the delivery of materials exclusively shifted into online due to the COVID-19 pandemic (Moorhouse, 2020) [4]. Everything was coming in suddenly, the applications were ready but the phenomenon is the teachers and student's readiness to use the application. Law of readiness proposed by Thorndike emphasizes that students should have appropriately enough background information before they are introduced to new data (Karadut, 2012) [5]. Even the technology is getting more sophisticated, but the use of these tools needs a guide. The guide can be a teacher, someone who is expert to operate this tool, or practice by himself searching how to use e-learning on YouTube. As a consequence, students should have technology literacy.

Technology has a big impact on our life. It influences our daily activities not only in the offices but also in schools and other places. We can use such as many applications for continuing our activities, especially in education. The use of e-learning applications is really helpful in the academic program such as Schoology, Moodle, Google Classroom and so forth. Liu (2019) [6] proposed online learning becomes an integral part of curriculum and instruction because of the ubiquity of online access to information and communication, the flexibility of time and place of learning, and development of online pedagogy. If students are adequately trained to use technology for language learning, their participation in online learning methods increases (Lai, Shum, \& Tian, 2016) [7]. There were abundant studies that have examined the use of e-learning applications in English teaching-learning. Some researchers focused on investigating such as the effectiveness of e-learning applications in teaching listening, speaking, reading, and writing. Others focused on how the use of an e-learning application is easy for teaching-learning at home In the area of teaching grammar using e-learning, there are several key studies worth revisiting. The use of Web-based Language Learning (WBLL) for teaching English helps a teacher to teach easier. However, it might be difficult for students who are used to learning offline. According to Yusof \& Saadon (2012) [8], WBLL materials are favorite materials used by English teachers since they are abundant, easily accessed, userfriendly and most importantly, they are provided for free. Türkmen (2016) [9] found that the use of online concordances and actual texts encouraged teaching grammar in EFL learning and teaching processes. She also found that teachers ought to combine online concordances into their classroom practices to educate grammar and vocabulary effectively.

Mohamad (2009) [10] has investigated two grammar teaching methods: internet-based grammar instruction (IBGI) and conventional pen and board instruction (CPBI). The researcher found that using IBGI was better than CPBI in learning grammatical items in Malaysia. It was also found that students who skilled IBGI made fewer errors in their essays than those of students who used CPBI. on the other hand, Thamrin, et al. (2019) [11] found that numerous constraints make the teaching-learning grammar not always effective. Some of the ineffective are lack of references, time and space. While students need more time to practice the language. Moodle is one piece of information technology contributes to being the solution of the limited time in teaching-learning grammar. Most students have a positive response towards the implementation of Moodle within the grammar teaching-learning process. Overall, almost all students respond that online learning instruction is needed. The researchers are interested in exploring the use of Google Classroom shifting which is caused by COVID-19 pandemic. Hence, this study shed light on exploring the adaptation of grammar teaching-learning using Google Classroom. This study attempts to investigate the leading questions: 1) How is the adaptation of the lecturer in ELT and learning by using Google 
Classroom?; 2) How are students' perceptions about learning grammar by using Google Classroom?; and 3) How are the impacts of the student's achievement on learning grammar by using Google Classroom?

\section{Literature Review}

\subsection{Online Learning}

Gonzales \& St. Louis (2018) [12] defined online learning as learning carried out from a distance assisted by electronic devices, for instance, tablets, smartphones, laptops, and computers which require an internet connection (Gonzales \& St. Louis, 2018) [12]. Furthermore, online learning in Indonesian EFL classrooms during COVID-19 pandemic are carried out fully because both teacher and students are not able to gather in a face-to-face classroom (Blake, 2011) [13]. As a consequence, the countries which are affected by this pandemic conduct the teaching-learning activity through an online one. The use of online education in China has increased exceedingly 200 Billion Yuan in 2017; there was an increase of $29.7 \%$ from the previous year (Manegre \& Sabiri, 2020) [14]. It happened since virtual classrooms have become the primary focus of the private education sector in online language learning (OLL).

Many researchers have investigated the use of technology in online learning. This online learning in Western has generally given positive impacts on students (Howland \& Moore, 2002) [15]. Those positive impacts have been showing by having advantages, for instance, enhanced interaction and participation (Vonderwell, 2003) [16]; learning flexibility and comfort (Gabriel, 2004) [17]; more effective compared to face-to-face learning (Gabriel, 2004) [17]; easy of accessing additional materials (Tichavsky, Hunt, Driscoll, \& Jicha, 2015) [18]; self-directed learning (Howland \& Moore, 2002) [15]; multiple perspectives (Gabriel, 2004) [17]; democratic learning (Ali, Hodson-Carlton, \& Ryan, 2004) [19]; self-confidence emerged in learning (Gabriel, 2004) [17]; and others. As a consequence, surely, online learning gave negative impacts also Online learners might be disturbed by some nuisances, for instance, overload information (Gabriel, 2004) [17]; lack of fast response (Vonderwell, 2003) [16]; missing visual cues (Howland \& Moore, 2002) [15]; time-consuming (Howland \& Moore, 2002) [15]; technical difficulties (Gabriel, 2004) [17]; lack of human interaction and community (Vonderwell, 2003) [16]; difficult to understand the learning objectives (Song, Singleton, Hill, \& Koh, 2004) [20]; inability to think and being online at the same time (Gabriel, 2004) [17]; and so on.

The previous researcher also observed the impact of Coronavirus in Indonesia (Zaharah, Kirilova, \& Windarti, 2020) [21], the ESL students perceptions in Saudi Universities (Layali \& Shlowiy, 2020) [22], strengths and weaknesses in India (Dhawan, 2020) [23], and lecturer adaptations in Hong Kong university Moorhouse, 2020 [4]. Furthermore, DiCicco (2016) [24] investigated students and teachers to evaluate their perspectives about the integration of Google Classroom into social studies instruction. The researcher found that all students increased their vocabulary quiz scores but limited their content knowledge. Apriyanti, et al. (2018) [25] found that Google Classroom caused efficiency and effectiveness in the process of teaching and learning of English Business Writing class. Thus, the teacher's creativity is needed, and the role of a teacher to decide the use of technology in the class is big. However, using this Learning Management System (LMS) in a writing class supported in decreasing paper usage. Al-Maroof \& Al-Emran (2018) [26] examined the factors that affect the students' 
acceptance of Google Classroom. They identified that both the Perceived Ease Of Use (PEOU) and Perceived Usefulness (PU) positively influenced the behavioral intention. They influenced the actual usage of Google Classrooms. This study helped the decision-makers of the higher educational institutions to have a better understanding of the effectiveness of using Google Classroom by their students. This study also helped the lecturer in measuring the level of students' acceptance of the previously mentioned technology. Mafa (2018) [27] also investigated Google Classroom for two semesters as a teaching and learning tool. Data collected was analyzed using graphs and bar charts. A social constructivism theory which entails that human beings learn their surroundings and experiences was adopted for this study. The outcomes from this study demonstrated that Google classroom is compelling in educating and learning as the outcomes demonstrated that it improves teaching and learning.

Heggart \& Yoo (2018) [28] proposed that the use of Google Classroom increased student participation and learning and improved classroom dynamics. This study revealed concerns about pace and user experience. These data were used to construct a framework to evaluate the use of online platforms; it identifies four concepts (pace, ease of access, collaboration and student voice/agency) that explore the usefulness of other online learning platforms, as well as pedagogical practice. Besides, Khalil, et al (2017) [29] found significant statistical differences between the experimental and control group when the Google Classroom application is applied on teaching efficiency of educational college students in each of its levels (planning, execute and evaluation) and in academic achievement in computers. Rahmad, et al. (2019) [30] found that the use of Google Classroom in learning made it easier for lecturers and students to manage lectures, especially in terms of task management. After applying the learning media in the form of Google Classroom, the results of student learning independence were significant, this was evidenced by the majority of students having high learning independence. The students also increased the ability of critical thinking.

Ballew (2017) [31] examined whether teachers' years of experience, grade level assignment, and subject matter influenced their perceptions of the technology-based Google Classroom. The chi-square test of independence was utilized to determine if a relationship was found between teachers' perceptions and the three variables. All three variables were found to have a relationship with teacher perceptions, thereby causing the null hypotheses to be rejected. The lecturer participants' responses regarding Google Classroom were found to be dependent upon their years of experience, grade level assignment, and subject matter. Google Classroom is a viable way to deliver educational content to wide audiences, it is available free to people in a limited version [32]. She researched the Statewide Area Health Education Centers (AHEC) Network in Georgia which resulted in Google Classroom as an appropriate method to deliver content in many multisystem settings, such as nonprofit hospital networks, grant partners, and nonprofit networks. In this study, the researchers explored the learning switch of a college which got impacted by the pandemic of COVID-19. The researchers found that one of the lecturers used Google Classroom as the tools of e-learning in teaching English. Occasionally, the lecturer and students have face to face in the classroom for teachinglearning activities. This pandemic forces the lecturer to be able to develop his knowledge of technology to teach the subject using e-learning. It also forces students to learn from home using e-learning.

\subsection{Grammar Teaching Learning}


Kayar \& Veyis (2020) [33] suggested that grammar should be taught functionally because it is viewed as a field that supports basic language skill. A teacher who teaches grammar surely cannot separate with other components of language for instance writing and reading. Raikhapoor (2020) [34] proposed that using native language is one way that can be used by teachers to deliver grammar lessons. Hua \& Li (2015) [35] stated to bring fun and meaning into grammar learning that is used in popular culture materials. Alian, Khodabandeh, \& Soleimani (2017) [36] found the effect of two different tasks, namely Computer Assisted Language Learning (CALL)-based tasks and written questions tasks had positive effects on the students' grammar achievement. While Bikowski (2018) [37] suggested collaborating on research at the classroom level for context-specific insights or with larger populations allows teachers to make more educated decisions regarding how best to use technology to teach grammar. There are many applications which can be used by students to learn so that they become self-directed learning because they keep on finding additional materials by themselves. Even more in this pandemic era, students should be autonomous because only they control their learnings.

The aim of teaching grammar argued by Thornburry (1999) [38] is to facilitate students comprehension and language production, rather than an end of itself. Then, he suggested that teachers should provide as much as possible grammar exposure, interaction, and practices. Accordingly, Ellis (2006) [39] argued that grammar is best taught to people who already have accumulated some ability towards the proper use of the language rather than to complete beginner or young children. Thus, teaching grammar is not appropriate for young learners. Evidence suggests that how teachers handle grammar is strongly influenced by their views about language learning, their beliefs about their students' needs and wants, and other contextual factors such as time (Farrell \& Lim, 2005) [40]. Teacher's knowledge determines his way in developing an instructional design. Borg (2013) [41] divided teacher cognition studies on grammar teaching under three categories in terms of their focus of inquiry: (i) teachers' knowledge of grammar; (ii) teachers' beliefs about grammar teaching; and (iii) practices and cognitions in teaching grammar.

\section{Methodology}

\subsection{The setting and participants}

This study used a descriptive qualitative method. The participants of this study were a lecturer and forty students of Sharia Management Business study in economic faculty with different backgrounds. It is in the second semester in one of the Islamic state universities in Indonesia. They live in urban and rural areas. English is taught as one of the obligatory subjects. The lecturer has five years teaching experience in the college and he has been a civil servant for two years.

\subsection{Data Collection}

The data of this study were collected through open-ended interviews and documentation. Formerly, the researchers develop interview protocols to avoid less directed interviews. The researchers conducted an open-ended interview toward twelve students through online interviews and messenger to elaborate their experiences during online learning using Google Classroom. The twelve participants were chosen by using purposive sampling. The interviews 
were conducted to gain information about their perceptions and challenges during experiencing online learning. The researchers also conducted interviews with the lecturer to gain information about his perception and adaptation on the shifting of face-to-face into online learning. The researcher interviewed respondents using mobile phones in Indonesian to get more detailed data. In the beginning, the researchers interviewed the lecturer about an elearning application that he used for teaching English. Then, the researchers interviewed the lecturer and students about the adaptation of teaching-learning by using Google Classroom. At last, the researchers interviewed students' perception about the implementation of Google Classroom in grammar teaching-learning. The researchers also collected documents of students' scores on grammar tests given to 40 students which consisted of tenses, passive voice, verbs, and parallel structure.

\subsection{Data Analysis}

The collected data were analyzed to generate the themes which can provide details on triangulation. First, all the qualitative data were peer-reviewed by the researchers. This peer debriefing process helped to show the reliability of the data interpretation. Several codes were generated while the data were reviewed. Second, the researchers closely re-read the entire data set and marked all the data with the codes produced. The researchers then reviewed the codes thoroughly and combined the relevant codes.

\section{Result and Discussion}

Based on connectionism, the lecturer adaptation and students' perceptions emerged in using Google Classroom for ELT and learning.

\subsection{Lecturer adaptation}

The lecturer has been ready with the application. He had a good adaptation to use elearning in the teaching process. He asked students to install the Google Classroom application. The students had to learn the materials. The lecturer gave a pdf extension of English materials which were put on the Google Classroom. The lecturer instructed the students to read the materials by downloading in Google Classroom. He also gave the chance to the students in discussing the material. The discussion took place in the chat room of Google Classroom. Some students got good impact in the use of ELT of grammar by using Google Classroom. The lecturer admitted that he gave the appropriate task because the tasks are easy. Similarly, Hampel (2006) [42] suggested that teachers should ensure that the tasks given should be appropriate to the medium used and teachers should also develop tasks which consider the affordances (e.g. the constraints and possibilities for making meaning) of the modes available.

"I inform the students of the WhatsApp group that I decided by using a web application (Google Classroom) to help my activity in teaching English. I chose Google Classroom because this tool can work without being installed on a laptop or mobile phone. I thought if students spend much on the internet quota, it will make them spend much money. The students joined the class on Google Classroom by signing up with their Gmail accounts and input the code of the meeting class that I have given. This application is easier than others. I solve problems by creating the easiest materials about tenses. I asked the students to read and 
understand the materials. If they did not understand, I asked them to write a comment. After the discussion finished, I gave a task using Google Form. The effect of grammar teachinglearning by using Google Classroom is some of the students have good result scores, but some of them also have poor scores." (L).

\subsection{Students' Perceptions}

The students had several perceptions about the applications of e-learning in grammar teaching-learning. The interview of the student's perception labelled the code as "S". This study identified the valid perception of the students in studying English by using Google Classroom. The perceptions are as follow:

\subsubsection{Positive Attitude}

\section{a) Enrich and Widen Students Knowledge}

One of the students admitted that she studied harder. Moreover, she was also active in doing exercises. She also had the bravery to ask the lecturer what she has not understood well. Learners can use the technology to actively enrich and widen their language knowledge (Inozu, Sahinkarakas, \& Yumru, 2010) [43]. This occurrence is also supported by Tichavsky et al. (2015) [18] found that through online learning, students could access additional materials.

"I did many exercises by downloading the exercises from Google." (S1)

\section{b) Ability to Afford the Internet Quota}

Some students did not have problems with internet quota because they could afford it.

"I didn't have a problem with my internet connection. I understood the points of the material. I could finish the assignment well. I liked the material given by my lecturer." (S2)

"I wasn't impacted by the internet quota and low internet connection. I could finish the assignments because I have already learned those materials in my secondary school. Furthermore, before starting the quizzes, he gave a simple example so that we had no difficulties in finishing the assignments." (S3)

\section{c) Ability to Understand the Materials}

Generally, students had different abilities to understand materials. They understood the points of the material. Most of them did the assignment well. They like the material given by the lecturer. The grammar materials given by the lecturer are understandable.

"I adored the technique of my lecturer in the teaching-learning activity. There weren't many tasks given to us so that the tasks didn't make us burdened." (S4)

\section{d) Increase Self-Confidence}

The use of Google Classroom made them increase their confidence. It might because their friends did not look at each other. It is in line with Gabriel (2004) [17] who revealed that learners gained their confidence as online learners. The students liked the lecturer's technique in teaching grammar. 
"I was also confident to ask my lecturer about confusing material by chatting in the discussion section." (S1)

"I didn't have any obstacles regarding online learning. Furthermore, I didn't have any problems with my internet quota and internet connection. The lecturer shared the materials followed by the tasks. I appreciated this learning model because some lecturers only gave assignments." (S5)

"The use of Google Classrooms did not need much internet quota than other applications. It is helpful for my learning activity. I could understand the material by myself using elearning because my lecture gave the easiest example. I could understand the material. My scores are also good but I liked to study in the classroom again. (S6)"

\section{e) Flexibility}

They also got additional time to submit the assignment. This flexibility could accommodate each student's learning preferences, either they submitted the task early or they preferred to work late because of other tasks to do. Moreover, this asynchronous online learning gave more flexibility. A study conducted by Zhao \& McDougall (2008) [44] reported that a learner got advantages of asynchronous online learning: flexible learning schedule and place-independence. Even a participant admitted that it was easier to achieve a high score because all of the students' efforts could be notified by the teacher. The lecturer gives additional time in a day for submitting the assignment.

"The use of Google Classroom was helpful in my learning activity. The time for submitting the assignment is flexible. This application did not need much internet connection like other applications. I could work by being a driver on online transportation." (S7)

\subsubsection{Negative Attitude}

\section{a) Prefer Studying at Classroom}

Many problems faced by the students during an e-learning classroom activity. The first one, the students preferred to study English grammar in the classroom than to study by using Google Classroom. The students' preferences are studying in the classroom. Occasionally, it happens because they had difficulties in understanding the material. The students were not confident when they wanted to ask about the material, they only kept silent. They did not understand grammar materials. Their unconfidence disturbed their learning activities. Sometimes they preferred to ask the material to their friends. The readiness of students was not good enough; they preferred to discuss with their friends.

"I would not ask about the material which I didn't understand. I was afraid my friends would laugh at me. Hence, I didn't give any comments about the materials that my lecturer has explained." (S8)

"According to me, I preferred to have face-to-face learning in a classroom. Since the structured system and the materials presented could be understood in detail. As a result, I could maximize my learning." (S9)

\section{b) Financial Problems}


The second is about the condition of students' parents' financial matters. As a result, they could not buy internet quota to facilitate their children in learning English by using Google Classroom. It is in line with Atmojo \& Nugroho (2020) [45], one of the teaching challenges during COVID-19 pandemic in Indonesia. In their study, students faced several difficulties due to the financial condition of students' families including lack of internet quota and stable internet connection. Unfortunately, since some students did not have enough internet quota, they could not join all the class meetings. The result was that they only joined several meetings. They could not download the material and only get incomplete material. Moreover, they could not understand the material well. Their parents could not earn enough money because they were getting impacted by the pandemic. If students could not buy quota, consequently they could not join in the Google Classroom meeting. Thus, they missed some of the materials. Each student had a different situation in understanding the use of Google Classroom as an e-learning application. In this case, several students did not submit the grammar assignments punctually. They also did not submit the assignment based on the deadline. One of the reasons was because of internet quota. It made students anxious.

"I liked to study in the classroom. I didn't need money to buy internet quota. My parents' financial condition was not good in lockdown condition. My parents did not give me money because staying at home means a holiday. On the other hand, I needed to buy internet quota. I apologized to my lecturer, and I was afraid I would get a bad score because I submitted my assignment late." (S10)

\section{c) Get Bored and Inadequacy Internet Connection}

Another obstacle experienced by students is that the students were bored with the use of an e-learning application. They preferred to meet their friends in college than meet on Google Classroom because they had difficulties. Kop \& Fournier (2010) [46] identified the uncertainties and complexity of interacting with technology that affects learner's motivation to have self-directed learning. Furthermore, they also had low internet connections at home. Manegre \& Sabiri (2020) [14] identified a disturbance for online language learning: poor internet connection which might give negative experience. Thus, they argued both lecturer and students should have adequate internet connection so that instructions and guidance could be transmitted effectively. On the other hand, good pedagogy will be nonsense if there are obstacles regarding technology access (Burston, 2014) [47]. In the college, the lecturer explains more about grammar, while in this pandemic COVID-19 the lecturer used Google Classroom by instructing the students to understand the materials by themselves. The students should be active in learning.

"I felt bored with e-learning because all lecturers used e-learning applications. Each lecturer used different applications. I could not go everywhere. I cannot see my friends' face. This application did not allow me to have good interaction with friends since not all of us had a strong internet connection. Moreover, my house is in a rural area, I had a bad internet connection. This makes me sad because I must also read so many materials." (S11)

\section{d) Low Digital Literacy}

The students got less readiness about the use of technology. Some students might have different abilities in technology literacy. The use of Google Classroom forced them to study more about technology. Levy (2009) [48] argued that it is a need for learners to evolve relevant competencies about the active and effective use of technology for language learning. 
The students practised operating the application. They were concerned with studying the application, conversely, they had less understanding of learning grammar materials.

"At first, I realized that I did not know more about the technology. I usually asked my friends in the classroom about how to operate some applications. My lecturer asked to sign up with my email on the Google Classroom. I felt confused, then I asked my friend by texting on WhatsApp. It took a long time because I didn't understand at first. Finally, I could operate it but I didn't like learning grammar by e-learning applications. It happened because it was difficult to understand the material." (S12)

\subsection{The Impact of Students achievements on Learning Grammar by Using Google Classroom}

In this study, the researcher analyzed the result of the test which was done by the students. These analyses have the purpose to describe the impact of online learning by using Google Classroom on students grammar achievements. The following are the tables of grammar test results. The tests were about tenses, passive voice, verbs, and parallel structure. The tables show the 3 highest of the score, 3 middle of score, and 3 lowest of the scores test result.

Table 1. Grammar test Result of the Tense

\begin{tabular}{cccccc}
\hline $\begin{array}{c}\text { The } 3 \text { highest } \\
\text { score }\end{array}$ & $\begin{array}{c}\text { Number of } \\
\text { students }\end{array}$ & $\begin{array}{c}\text { The } 3 \text { moderates } \\
\text { of score }\end{array}$ & $\begin{array}{c}\text { Number of } \\
\text { students }\end{array}$ & $\begin{array}{c}\text { The } 3 \text { lowest } \\
\text { of score }\end{array}$ & $\begin{array}{c}\text { Number } \\
\text { of students }\end{array}$ \\
\hline 100 & 6 & 70 & 2 & 40 & 1 \\
90 & 11 & 60 & 8 & 30 & 1 \\
80 & 7 & 50 & 3 & 20 & 1 \\
\hline
\end{tabular}

Table 1 indicates that there were six, eleven, and seven students who achieved the three highest scores 100, 90, and 80 respectively. Furthermore, there were two, eight, and three students gaining the three moderate scores 70, 60, and 50 respectively. Moreover, three students were gaining the lowest score. It means that most of the students achieved good scores $(92.5 \%)$. However, there were only 3 students who achieved the lowest score $(7.5 \%)$.

Table 2. Grammar Test Result of Passive Voice

\begin{tabular}{cccccc}
\hline $\begin{array}{c}\text { The 3 highest } \\
\text { score }\end{array}$ & $\begin{array}{c}\text { Number } \\
\text { of students }\end{array}$ & $\begin{array}{c}\text { The 3 moderates } \\
\text { of score }\end{array}$ & $\begin{array}{c}\text { Number } \\
\text { of students }\end{array}$ & $\begin{array}{c}\text { The 3 lowest } \\
\text { of score }\end{array}$ & $\begin{array}{c}\text { Number of } \\
\text { students }\end{array}$ \\
\hline 100 & 7 & 70 & 5 & 40 & 3 \\
90 & 7 & 60 & 6 & 30 & 1 \\
80 & 6 & 50 & 3 & 20 & 2 \\
\hline
\end{tabular}

Table 2 gave us a notion about the distribution score of passive voice. It showed that twenty of the students got the three highest scores. The students who got 100 were seven students, while there were seven students also who got 90, and there were six students who got 80. Next, the results of the test in the three middle scores were 70, 60, and 50. Students who got score 70 were five, followed by six students who got score 60 and followed by three students who got score 50. Conversely, many students got the lowest scores (sixteen students). Three of them got to score 40, one of them got to score 30, and twelve students got score 20 . Fifty percent of students got the highest score, thirty-five percent of students got moderate scores, while the students who achieved the lowest scores were fifteen percent.

Table 3. Grammar Test Result of Verb

\begin{tabular}{llllll}
\hline The 3 highest & Number & The 3 moderates & Number & The 3 lowest & Number of \\
\hline
\end{tabular}




\begin{tabular}{cccccc}
\hline score & of students & of score & of students & of score & students \\
\hline 100 & 2 & 70 & 1 & 40 & 3 \\
90 & 7 & 60 & 7 & 30 & 0 \\
80 & 7 & 50 & 5 & 20 & 0 \\
\hline
\end{tabular}

From Table 3, it revealed the distribution of grammar test results in the verb test. The students who got the highest score were more than those who got the middle and the lowest ones. There were only two students who got score 100, while there were seven students who got score 90, and seven students got to score 80. Next, students who got the three middle scores $(70,80$ and 90$)$ respectively were one, seven, and five students. Conversely, there were only a few students who got the lowest scores. There were only three students who got a score of 40 , while there was no one who got both a score of 30 and 20 . Thus, $40 \%$ of students achieved the highest scores, $32.5 \%$ of the students who achieved moderate scores, and $7.5 \%$ of students achieved the lowest scores. Most of the students understood the use of appropriate verbs in a sentence, it can be seen it was found that $7.5 \%$ of them got the lowest score (40).

Table 4. Grammar test Result of Parallel Structure

\begin{tabular}{cccccc}
\hline $\begin{array}{c}\text { The 3 highest } \\
\text { score }\end{array}$ & $\begin{array}{c}\text { Number } \\
\text { of students }\end{array}$ & $\begin{array}{c}\text { The 3 moderates } \\
\text { of score }\end{array}$ & $\begin{array}{c}\text { Number } \\
\text { of students }\end{array}$ & $\begin{array}{c}\text { The 3 lowest } \\
\text { of score }\end{array}$ & $\begin{array}{c}\text { Number of } \\
\text { students }\end{array}$ \\
\hline 100 & 14 & 70 & 3 & 40 & 1 \\
90 & 12 & 60 & 2 & 30 & 0 \\
80 & 5 & 50 & 3 & 20 & 0 \\
\hline
\end{tabular}

The above Table 4 showed that most of the students got high scores. For score 100, there were fourteen students. Then, twelve students got a score of 90 . Five students got a score of 80 . The three middle scores $(70,60$, and 50$)$ were achieved conversely by three, two, and three students. On the other hand, the three lowest scores were 40, 30, and 20. It can be seen that only a student who got a score of 40 . Therefore, 77.5 percent of students got their best scores, 20 percent of students got their moderate scores, while 2.5 percent remained who got the lowest score. It can be concluded that students could understand the materials related to parallel structure.

Table 5. The Average Score of Grammar Test

\begin{tabular}{ccc}
\hline Grammar Test & Average score & Scale score \\
\hline Tenses & 75,25 & 3.00 \\
Passive voice & 73,33 & 3.00 \\
Verbs & 74,46 & 3.00 \\
Parallel structure & 85,00 & 3.50 \\
Total all average score & 77,01 & 3.25 \\
\hline
\end{tabular}

Based on table 5, The tests about tenses, passive voice, verbs, and parallel structure were conducted and the total average score is 77,01 or 3,25/4.00. All of the students have different learning strategies. The implementation of Google classroom in ELT learning English especially grammar provides a different impact for the students. Most of the able students often do some exercise about grammar and have a good internet connection. Finally, they gain a good score. The students who do not do the exercise of grammar and have a bad internet connection. Finally, they gain a poor score. The impact of teaching-learning grammar using Google Classroom is that most of the students achieved moderate scores on grammar tests. It means that the use of google classroom in learning English gave a good impact on the ability of the students of grammar. Ahmadi, 2018 also mentioned the use of technology improving the student's language skills. 


\section{Conclusion}

COVID-19 pandemic gives an impact on the education program in ELT and Learning. It requires students to adjust e-learning applications. The students have not been ready to operate the applications. The results showed that the lecture created grammar materials on pdf, gave the assignment and resulted in the students' work on Google Classroom. The students perceived that they preferred to study in the classroom to Google Classroom because they had a bad internet connection. The tests about tenses, passive voice, verbs, and parallel structure were conducted and the average score was 3,25/4.00. Considering it as a privilege, this study shows Google Classroom can be used in teaching-learning English especially on grammar. Even there is a positive and negative impact on the students. Most of the students can study at home online and also get good scores. The negative impact is the students who do not have money to buy quota, the students who have bad internet connection get poor scores. Based on the interview result showed that the lecture adaptation in the COVID-19 pandemic. He immediately made a strategy in teaching grammar, the students also participated in the elearning classroom activity. While there is a problem faced with an internet connection with some of the students. For the next study, it is highly recommended that the teacher needs to design any strategy in teaching grammar and prepare any solutions if the students could not join the online learning.

\section{References}

[1] A. Prasetia, "Jokowi: Kuliah Daring Dulu Lamban Dijalankan, Sekarang Telah Jadi New Normal," detik.com, 2020. [Online]. Available: https://news.detik.com/berita/d5079635/jokowi-kuliah-daring-dulu-lamban-dijalankan-sekarang-telah-jadi-newnormal? ga=2.231931417.727509942.1593834203-1330201502.1593834203. [Accessed: 04-Jul-2020].

[2] M. McAleer, "Prevention Is Better Than the Cure: Risk Management of COVID-19," J. Risk Financ. Manag., vol. 13, no. 3, p. 46, 2020.

[3] A. Mustofa, "Online Learning di Tengah Pandemi Covid-19," Jawapos.com, 2020. [Online]. Available: https://radarbali.jawapos.com/read/2020/04/24/190653/onlinelearning-di-tengah-pandemi-covid-19. [Accessed: 14-Jul-2020].

[4] B. L. Moorhouse, "Adaptations to a face-to-face initial teacher education course 'forced' online due to the COVID-19 pandemic," J. Educ. Teach., pp. 1-3, 2020.

[5] A. P. Karadut, "Effects of E. L. Thorndike's Theory of Connectionism Rudiments on Developing Cello Playing Skills for Beginners," Procedia - Soc. Behav. Sci., vol. 69, no. Iceepsy, pp. 298-305, 2012.

[6] J. C. Liu, "Evaluating Online Learning Orientation Design with a Readiness Scale," Online Learn. J., vol. 23, no. 4, pp. 42-61, 2019.

[7] C. Lai, M. Shum, and Y. Tian, "Enhancing learners' self-directed use of technology for language learning: the effectiveness of an online training platform," Comput. Assist. Lang. Learn., vol. 29, no. 1, pp. 40-60, 2016.

[8] N. A. Yusof and N. Saadon, "The Effects of Web-based Language Learning on University Students' Grammar Proficiency," Procedia - Soc. Behav. Sci., vol. 67, no. November 2011, pp. 402-408, 2012. 
[9] Y. Türkmen, "The Effects of Using Online Concordancers on Teaching Grammar/Çevrimiçi Derlem Kullanımının Dilbilgisi Öğretimine Etkileri,” Atatürk Üniversitesi Sos. Bilim. Enstitüsü Derg., vol. 20, no. 1, pp. 0-0, 2016.

[10] F. Mohamad, "Internet-based Grammar Instruction in the ESL Classroom," Int. J. Pedagog. Learn., vol. 5, no. 2, pp. 34-48, 2009.

[11] N. S. Thamrin, A. Suriaman, and M. Maghfirah, "Students' Perception on the Implementation of Moodle Web-Based in Learning Grammar," IJOLTL Indones. J. Lang. Teach. Linguist., vol. 4, no. 1, pp. 1-10, 2019.

[12] D. Gonzales and R. St. Louis, “Online learning,” Encycl. Hum. Comput. Interact., pp. $1-6,2018$.

[13] R. J. Blake, "Current trends in online language learning," Annu. Rev. Appl. Linguist., vol. 31, pp. 19-35, 2011.

[14] M. Manegre and K. A. Sabiri, "Online language learning using virtual classrooms: an analysis of teacher perceptions," Comput. Assist. Lang. Learn., vol. 0, no. 0, pp. 1-16, 2020.

[15] J. L. Howland and J. L. Moore, "Student perceptions as distance learners in internetbased courses," Distance Educ., vol. 23, no. 2, pp. 183-195, 2002.

[16] S. Vonderwell, "An examination of asynchronous communication experiences and perspectives of students in an online course: A case study," Internet High. Educ., vol. 6, no. 1, pp. 77-90, 2003.

[17] M. a Gabriel, "Learning Together: Exploring Group Interactions Online," J. Distance Educ., vol. 19, no. 1, pp. 54-72, 2004.

[18] L. P. Tichavsky, A. Hunt, A. Driscoll, and K. Jicha, "'It's Just Nice Having a Real Teacher': Student Perceptions of Online versus Face-to-Face Instruction," Int. J. Scholarsh. Teach. Learn., vol. 9, no. 2, 2015.

[19] N. S. Ali, K. Hodson-Carlton, and M. Ryan, "Students' perceptions of online learning: implications for teaching.," Nurse Educ., vol. 29, no. 3, pp. 111-115, 2004.

[20] L. Song, E. S. Singleton, J. R. Hill, and M. H. Koh, "Improving online learning: Student perceptions of useful and challenging characteristics," Internet High. Educ., vol. 7, no. 1, pp. 59-70, 2004.

[21] Z. Zaharah and G. I. Kirilova, "Impact of Corona Virus Outbreak Towards Teaching and Learning Activities in Indonesia," SALAM J. Sos. dan Budaya Syar-i, vol. 7, no. 3, 2020 .

[22] K. Layali, P. Academy, and A. Al Shlowiy, "Students' Perceptions of e-Learning for ESL / EFL in Saudi Universities and their Implications during Coronavirus Pandemic : A Review of Literature," no. June, 2020.

[23] S. Dhawan, "Online Learning: A Panacea in the Time of COVID-19 Crisis," J. Educ. Technol. Syst., p. 004723952093401, 2020.

[24] K. M. DiCicco, "The effects of Google Classroom on teaching social studies for students with learning disabilities," Theses Diss. 1583., p. 64, 2016.

[25] D. Apriyanti, H. Syarif, S. Ramadhan, M. Zaim, and A. Agustina, "Technology-Based Google Classroom In English Business Writing Class," in Seventh International Conference on Languages and Arts, 2018, vol. 301, pp. 689-694.

[26] R. A. S. Al-Maroof and M. Al-Emran, "Students acceptance of google classroom: An exploratory study using PLS-SEM approach," Int. J. Emerg. Technol. Learn., vol. 13, no. 6 , pp. 112-123, 2018.

[27] K. R. Mafa, "Capabilities of Google Classroom as a Teaching and Learning Tool in Higher Education,” Int. J. Sci. Technol. Eng. |, vol. 5, no. 5, pp. 3-8, 2018. 
[28] K. R. Heggart and J. Yoo, "Getting the most from google classroom: A pedagogical framework for tertiary educators," Aust. J. Teach. Educ., vol. 43, no. 3, pp. 140-153, 2018.

[29] Z. M. Khalil, S. Abdelrahman, O. Basher, and S. Chauhan, "The impact of google classroom application on the teaching efficiency of pre-teachers," Int. J. Soc. Sci. Educ., vol. 2, no. 2, pp. 33-48, 2017.

[30] R. Rahmad, M. Adria Wirda, N. Berutu, W. Lumbantoruan, and M. Sintong, "Google classroom implementation in Indonesian higher education," J. Phys. Conf. Ser., vol. 1175 , no. $1,2019$.

[31] T. D. Ballew, "Teacher Perception of a Technology Based on Google classroom," Carson-Newman University, 2017.

[32] D. Ballance, "E Pluribus Unum: Using Google Classroom to Bring Together a Statewide Student and Faculty Cohort," J. Hosp. Librariansh., vol. 20, no. 02, pp. 1-6, 2020.

[33] A. Kayar and F. Veyis, "An Analysis of Grammar Teaching in Secondary School in Terms of Success, Attitude and Teachers 'Views," Asian J. Educ. Train., vol. 6, no. 2, pp. 149-160, 2020.

[34] Raikhapoor, "Teachers' Beliefs and Practices on Teaching Grammar," in 1st International Conference on Education, Society, Economy, Humanity and Environment (ICESHE 2019), 2020, vol. 414, no. Iceshe 2019, pp. 65-68.

[35] C. Hua and B. Li, "Bringing fun and meaning into grammar learning: A case study of a secondary-level EFL class in Hong Kong," Cogent Educ., vol. 2, no. 1, 2015.

[36] J. ed-din Alian, F. Khodabandeh, and H. Soleimani, "The effect of MALL-based tasks on EFL learners' grammar learning," Teach. English with Technol., vol. 17, no. 2, pp. 29-41, 2017.

[37] D. Bikowski, “Technology for Teaching Grammar," TESOL Encycl. English Lang. Teach., no. July, pp. 1-7, 2018.

[38] S. Thornburry, How to Teach Grammar, vol. 51. Harlow: Longman, 1999.

[39] R. Ellis, "Current issues in the teaching of population.," TESOL Q., vol. 40, no. 1, pp. 83-107, 2006.

[40] T. Farrell and P. Lim, "Conceptions of Grammar Teaching: A Case Study of Teachers' Beliefs and Classroom Practices.," Tesl-Ej, vol. 9, no. 2, pp. 1-13, 2005.

[41] S. Borg, "Teacher cognition in language teaching: A review of research on what language teachers think, know, believe, and do Review article Teacher cognition in language teaching: A review of research on what language teachers think, know, believe , and do," no. May 2003, 2013.

[42] R. Hampel, "Rethinking task design for the digital age: A framework for language teaching and learning in a synchronous online environment," $\operatorname{ReCALL}$, vol. 18, no. 1, pp. 105-121, 2006.

[43] J. Inozu, S. Sahinkarakas, and H. Yumru, "The Nature of Language Learning Experiences beyond the Classroom and Its Learning Outcomes," US-China Foreign Lang., vol. 8, no. 1, pp. 14-22, 2010.

[44] N. Zhao and D. McDougall, "Cultural Influences on Chinese Students' Asynchronous Online Learning in a Canadian University.," J. Distance Educ., vol. 22, no. 2, pp. 5979, 2008.

[45] A. E. P. Atmojo and A. Nugroho, "EFL Classes Must Go Online! Teaching Activities and Challenges during COVID-19 Pandemic in Indonesia," Regist. J., vol. 13, no. 1, pp. 49-76, 2020. 
[46] R. Kop and H. Fournier, "New dimension of self-directed learning in an opennetworked learning environment.," Int. J. Self-Directed Learn., vol. 7, no. 2, pp. 1-20, 2010.

[47] J. Burston, "MALL: The pedagogical challenges," Comput. Assist. Lang. Learn., vol. 27, no. 4, pp. 344-357, 2014.

[48] M. Levy, "Technologies in Use for Second Language Learning All use subject to JSTOR Terms and Conditions Technologies Language in Use Learning for Second," Mod. Lang. J., vol. 93, pp. 769-782, 2009. 